\title{
IIIIIIIIIIIT \\ Tissue reaction and anti-biofilm action of new biomaterial composed of latex from Hancornia speciosa Gomes and silver nanoparticles
}

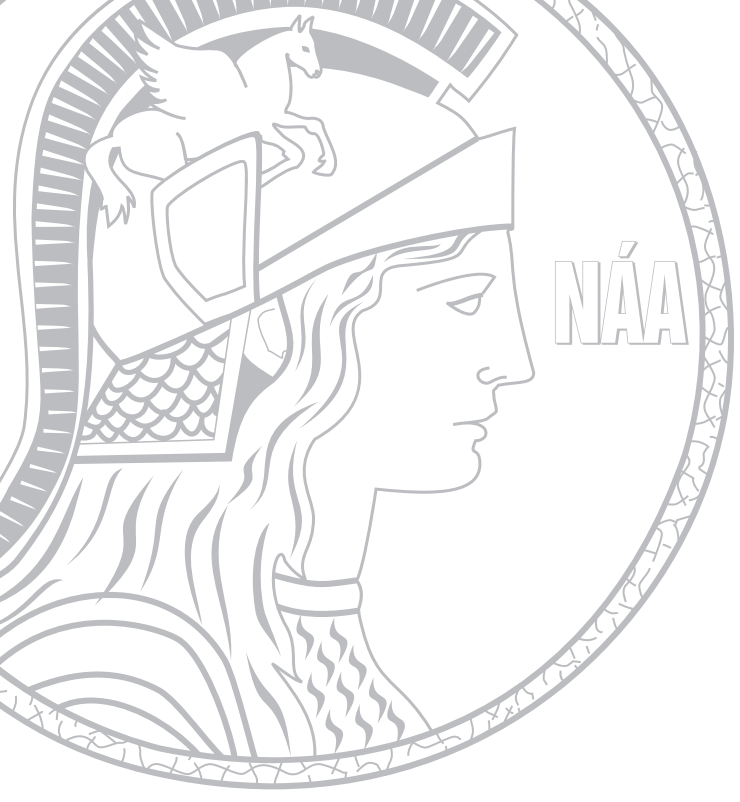

\author{
JÉSSICA M. BONETE, GUILHERME D. SILVA, ÉDER J. GUIDELLI, PABLO J. \\ GONÇALVES, LUCIANE M. ALMEIDA, OSWALDO BAFFA \& ANGELA KINOSHITA
}

\begin{abstract}
In this work, the natural latex extracted from Harconia speciosa was incorporated with silver nanoparticles (AgNP) to compose a functional biomaterial associating the intrinsic angiogenic activity of the latex and the antimicrobial activity of AgNP. Tissue reaction after subcutaneous implantation in dorsum of rats of membranes without AgNP and with 0.05\%, 0.4\% AgNP was compared at 3, 7 and 25 days. No statistically significant difference in the tissue response of the different biomaterials was observed, indicating that AgNP did not interfere with the inflammatory reaction ( $p$ $>0.05$ ) or with the angiogenic activity of latex. Biomembranes were also tested against bacterial biofilm formation by Staphylococcus aureus and the antimicrobial activity of the new biomaterial can be found with bacteria crenation (0.05\% AgNP) and no biofilm deposition ( $0.4 \%$ AgNP). Therefore, this biomaterial has interesting properties for the tissue repair process and may be feasible for future applications as dressing.
\end{abstract}

Key words: antimicrobial activity, biomembrane, biocompatibility, inflammation, silver nanoparticle, wound dressings.

\section{INTRODUCTION}

Hancornia speciosa (mangabeira) is a native species from Brazil that belongs to the family Apocynaceae and occurs in coastal and coastal littoral areas in the Northeast, Midwest, North and Southeast regions. In the last century there was little extraction and commercialization of mangabeira latex for rubber production due to the low productivity of its latex compared to the rubber tree (Hevea brasiliensis L.); its use remaining only in popular medicine (Junior et al. 2017, Soares et al. 2004, Medeiros et al. 2010). Since then, the interest for its phytotherapeutic potential in tissue repair has been increasing.

Ethanolic extract obtained from the leaves of the mangabeira promoted increased migration and proliferation of fibroblasts in artificial wounds, a factor considered important in the process of wound healing (Geller et al. 2015). In addition, latex of $H$. speciosa exhibits no toxic effects, and demonstrated anti-inflammatory effect, inhibiting the production of cytokines, nitric oxide, PGE2 and inflammatory cell migration (Marinho et al. 2011, Torres-Rêgo et al. 2016). Toxicity experiments in the root model of Allium cepa and fibroblast mouse cells, showed that $H$. speciosa latex does not present cytotoxic effects (Almeida et al. 2014, Ribeiro et al. 2016).

Studies with natural latex membranes have demonstrated usefulness in the process of neoformation and tissue regeneration (Borsari et al. 2014, Frade et al. 2001). Latex membranes of $\mathrm{H}$. brasiliensis have already demonstrated 
efficiency as an occlusive barrier promoting an increase of bone neoformation in guided bone regeneration processes (Ereno et al. 2010, Moura et al. 2014). Latex biomembranes of $H$. brasiliensis and $H$. speciosa, have both proven to be effective in the bone repair process (dos Santos Neves et al. 2016, Floriano et al. 2016). Rubber latex has high pharmacological potential in the repair process, however. protein content of allergenic potential in its composition is a concern (Berthelot et al. 2012, Ebo \& Stevens 2002). In contrast, the latex of $H$. speciosa, compared to rubber tree $H$. brasiliensis, presents a lower protein content (Malmonge et al. 2009), which favors its use in biomembranes. Therefore, $H$. speciosa latex biomembranes may be an interesting alternative for aiding healing processes.

The unique properties of silver nanoparticles has increased their use in several applications in the medical area, among them as a therapeutic agent (Zhang et al. 2008), in treatments of wound infections and skin burns (Wilkinson et al. 2011), ulcers and cutaneous healing process (Ahamed et al. 2010, Carter et al. 2010, International Consensus 2012). The constant release of $\mathrm{Ag}^{+}$ ions, providing greater antimicrobial efficacy (Rai et al. 2009) providing the reduction of infections and, consequently, the use of antibiotics and treatment costs (Chaloupka et al. 2010). AgNPs demonstrate to be highly efficient antimicrobial agent (Kim et al. 2007) and bacterial anti-biofilms (Radzig et al. 2013). So, the insertion of AgNPs in the composition of biomaterials aims to reduce the amount of microorganisms (Chambers et al. 2007).

Anti-inflammatory effects after application of AgNP were identified and compared to drugs already marketed (Hebeish et al. 2014). So, antiinflammatory action is a relevant factor for latex binding of $H$. speciosa and AgNP. In this work, AgNPs were incorporated in the latex of
$H$. speciosa forming a biomembrane, aiming to assist in the tissue repair process, to combat infections and to avoid the formation of bacterial biofilms. Analysis of tissue reaction in vivo after implantation, antimicrobial activity and anti-biofilm in vitro were performed. The development of efficient biomaterials in the treatment of non-healing wounds, aims to reduce the physical and psychological suffering of patients, as well as the treatment costs, thus being of great relevance for public health.

\section{MATERIALS AND METHODS}

\section{Synthesis of Silver Nanoparticles (AgNPs)}

Silver nanoparticles were obtained by chemical reduction of silver nitrate $\mathrm{AgNO}_{3}$ (aqueous solution $8 \mathrm{mM}$ ) by sodium borohydride $\mathrm{NaBH}_{4}$ (aqueous solution $16 \mathrm{mM}$ ), using miliQ ultrapure water as a solvent. The AgNP solution was obtained by mixing the $\mathrm{AgNO}_{3}$ and $\mathrm{NaBH}_{4}$ solution under constant stirring at $1800 \mathrm{rpm}$ at room temperature. The system was kept under stirring for 1 hour in order to guarantee the total reduction of the Silver, based on methods already described Guidelli et al. (2013). The formation of the AgNPs was confirmed by the formation of a solution of yellowish or brown color and presence of the plasmonic peak in the UV-Vis spectrum of the solution, around $500 \mathrm{~nm}$.

\section{Membranes preparation}

The latex of $H$. speciosa was collected from Goiás State University tree collection, in the city of Ipameri, (Goiás State, Brazil). A voucher specimen was deposited at the University Herbarium (Goiás State University, Anápolis, Goiás, Brazil) and the exsiccate received number 4875. The latex was collected in a sterilized container by an incision in the bark of the plant. The cut was approximately $10 \mathrm{~cm}$ long and 0.5 $\mathrm{cm}$ deep. Ultrapure water was added in a ratio 
of 1:1 (latex:water) to avoid coagulation. The latex was centrifuged for $5 \mathrm{~min}$ at $3500 \mathrm{rpm}$ to remove the impurities collected during the collection process (Almeida et al. 2014), and in sequence kept under refrigeration at $15^{\circ} \mathrm{C}$. The membranes were synthesized by adapting the methodologies used by Guidelli et al. (2013) and Almeida et al. (2019). Firstly, the LS underwent drying to calculate the amount of rubber. Afterwards, the solutions of LS + AgNP were prepared according to the final concentration of $\mathrm{Ag}$ of $0.05 \%$ and $0.4 \%$, homogenizing under agitation for $10 \mathrm{~min}$. The solutions LS + AgNP $0.05 \%$ and $L S+A g N P 0.4 \%$ were poured into Petri dishes (5.00 $\pm 0.05 \mathrm{~cm}$ in diameter), divided into steps, $2 \mathrm{~mL}$ in each step, and left at $45^{\circ} \mathrm{C}$, assuring the homogeneity of the membranes until complete polymerization. Pure LS was used for the L0\% biomembrane (without AgNP). The membranes were removed from the Petri dishes with the aid of forceps and cut $1 \mathrm{~cm}^{2}$.

The membranes were sterilized by gamma irradiation from Gammacell 220 Cobalt-60 source, at $25 \mathrm{kGy}$ dose for in vivo and in vitro tests. The surfaces of the biomembranes $\mathrm{L} 0 \%$, L0.05\% and L04\% were observed using a Zeiss ${ }^{\circledR}$ EVO 50 (20 KV) Scanning Electron Microscopy (SEM) image analysis.

\section{Subcutaneous implant - in vivo experiment}

This study was approved by the Committee of Ethics in Animal Use at the Universidade do Sagrado Coração, protocol n 8517260416, and they follow the Guidelines of Integrity and Good Practices for Production, Maintenance or Use of Animals in Teaching or Scientific Research Activities of the National Control Council of Animal Experimentation. Eighteen males Rattus norvegicus albinus Wistar rats weighing between 250 and 280 g, provided by the Universidade do Sagrado Coração, São Paulo, Brazil, were used. The animals were kept in plastic boxes, fed with water and ad libitum feed, in an environment with controlled temperature and light (cycle of 12 hours) throughout the experiment period. For the subcutaneous implantation procedure, the animals were sedated with intraperitoneal xylazine hydrochloride $(10 \mathrm{mg} / \mathrm{kg}$ ) intraperitoneal (Rompum ${ }^{\circledR}$, Bayer) intraperitoneal anesthetic administration followed by intraperitoneal administration of ketamine hydrochloride (90 mg / kg) (Dopalen, Vetbrands). This surgical model was based on the methods described by Marques et al. (2013) and Van Minnen et al. (2005). In the dorsal region of each animal three surgical incisions were made with a sterile scalpel with $5 \mathrm{~mm}$ of diameter and $2 \mathrm{~cm}$ of distance between each incision. In each incision, a biomembrane of each group was implanted in the subcutaneous tissue, LO\%, L0.05\% and L0.4 $\%$. After surgery, analgesic paracetamol (Tylenol ${ }^{\circledR}$, Janssen) $2 \mathrm{mg} / \mathrm{mL}$ diluted in drinking water was administered for a period of 48 hours. The periods of observation were 3, 7 and 25 days. Six animals were submitted to euthanasia in each period, by inhalation of the general anesthetic dosage Isoflurane (Vetflurano ${ }^{\circledR}$, Virbac). The biomaterials were removed and collected together with surrounding tissue, including epidermal and subcutaneous tissue, followed by fixation in 10\% formaldehyde for 48 hours, followed by conventional histological processing. There was a total of 6 samples for each experimental group in each of the periods $(n=6)$.

\section{Histopathological analysis}

Histological sections were obtained in a transverse direction with a thickness of 6 micrometers and stained with hematoxylineosin (HE). The photomicrographs were obtained in a standardized way with a Nikon Eclipse $80 \mathrm{i}$ microscope and the Image-Pro ${ }^{\circledR}$ Plus software, at 20x, 400x magnifications. In the 20x 
magnification images, it is possible to visualize the biomaterial implanted in the subcutaneous tissue and the epidermis with hair follicles in the upper region. The contact surface of the biomaterial with the subcutaneous tissue was the region of interest, in this region six areas were delimited for the capture of histological images, the following areas were selected: in the upper left and right region between subcutaneous and epidermis, lower left and right region between the subcutaneous and the muscular tissue and on the right and left sides with 400x magnification. Subsequently, the Image image processing and analysis program (Schneider et al. 2012) was used to count the infiltrating inflammatory cells (mononuclear, polymorphonuclear and giant cells) and new blood capillaries. Statistical analysis was performed with OriginLab (c) (Massachusetts, USA). Data comparison was performed using Kruskal Wallis non-parametric test, StudentNewman-Keuls, $p<0.05$.

\section{In vitro antimicrobial assays}

\section{Bacterial inoculum}

The bacterial inoculum was prepared by the addition of some colonies of Staphylococcus aureus (ATCC 25923, clinical isolate) in $5 \mathrm{~mL}$ of RPMI 1640 culture medium with glutamine (HyClone ${ }^{\mathrm{TM}}, \mathrm{EUA}$ ) and incubated under agitation at $120 \mathrm{rpm}$ for 22 hours at $37^{\circ} \mathrm{C}$. After overnight incubation, it was centrifuged at 5,000 rpm and washed twice in 1X PBS (phosphatebuffered saline). After final resuspension in $1 \mathrm{X}$ PBS, the optical density at $600 \mathrm{~nm}$ (OD600) was measured using spectrophotometer (BEL Photonics ${ }^{\circledR}$; Spectrophotometer SP1105). Based on the OD600 obtained, the cell suspension was diluted in RPMI to the concentration of $10^{7}$ cells / $\mathrm{mL}$.

\section{Biofilm adhesion}

L0\% was used as negative control (without AgNP) and $\mathrm{L} 0.05 \%$ and $\mathrm{L} 0.4 \%$ (with AgNP). For adhesion of the cells suspended on the surface of the membranes, 6 samples of each membrane with $1 \mathrm{~cm}^{2}$ were placed in 24-well plates (Kasvi ${ }^{\circledR}$ ). Each well received $2 \mathrm{~mL}$ of inoculum $10^{7}$ cells $/ \mathrm{mL}$, followed by incubation at $37^{\circ} \mathrm{C}$ under agitation at $75 \mathrm{rpm}$ for $90 \mathrm{~min}$. After incubation, the membranes were washed with $2 \mathrm{~mL}$ phosphatebuffered saline solution ( $\mathrm{pH}-7.2)$ to remove unbound bacteria.

L0.05\% and L0.4\% and LO\% biomembranes were transferred to new sterile plates. Again 2 $\mathrm{mL}$ of RPMI culture medium were added to each well, followed by incubation under agitation at 75 $\mathrm{rpm}, 37^{\circ} \mathrm{C}$ for 24 hours. After the $24 \mathrm{~h}$ incubation, the membranes were washed in PBS to remove unbound cells, fixed with $2 \mathrm{~mL}$ of methanol for 15 minutes.

\section{Colorimetric masurement for biomass determination}

The membranes L0\%, L0.05\% and L0.4\% inoculated by the same procedure previously mentioned, after $24 \mathrm{~h}$ of incubation and fixation in methanol, were immersed in $1 \%$ gentian violet for $5 \mathrm{~min}$ and washed in PBS to remove excess dye. The biofilm biomass was measured by reading optical density at 570nm (OD570) of the dye absorbed by the adhered cells, using samples of uncontaminated membranes as reference. Afterward, the biofilm-associated dye was solubilized in 33\% acetic acid and OD was measured on the UV-Vis spectrophotometer, based on previously published methods (Christensen et al. 1985, Kalishwaralal et al. 2010, Radzig et al. 2013). The results obtained for the groups L0\%, L0.05\% and L0.4\%, were compared by non-parametric test with Kruskal Wallis ( $p$ $<0.05$ ). 


\section{Scanning electron microscopy (SEM)}

For SEM images, membranes L0\%, L0.05\% and L0.4\% test samples contaminated with S. aureus and uncontaminated were washed in 1X PBS (phosphate-buffered saline) 3 times and then fixed in $10 \%$ formaldehyde for $1 \mathrm{~h}$, at room temperature. The dehydration process was done with ethanol $(70 \%, 85 \%, 100 \%)$ for 5 minutes in each solution. All samples were transferred to a new sterile 24-well plastic plate, stored for SEM images, without exposure to light.

For SEM imaging, the specimens were coated with a gold layer of $10 \pm 2 \mathrm{~nm}$. The images were obtained with scanning electron microscope ZEISS EVO 50, for analysis of formation and morphology of the biofilm in the contaminated samples, and the surface of the membrane in the uncontaminated samples. Three samples ( $n$ = 3 / group) were used for each experimental group.

\section{RESULTS}

\section{Biomembranes}

SEM images show the surface details of latex biomembranes polymerized at $40^{\circ} \mathrm{C}$, with different concentrations of AgNP (Figure 1). The surface of the latex membranes did not present pores, however L0\% (Figure 1a) presented a surface with a higher roughness, compared to the surface of L0.05\% (Figure 1b) and L0.4\% (Figure 1c) with a flatter appearance. The crystalline element with monoclinic structure of the crystals suggest that they are due to sugars present in the latex.

\section{Tissue reaction}

After 3 days postoperative, intense inflammatory infiltration, with predominance of polymorphonuclear cells (Figure 2a) in all groups, was identified in the tissue surrounding the implanted biomaterials. Fibroblasts and deposition of collagen fibers could also be observed, connective tissue regeneration. L0\% presented lower infiltration of polymorphonuclear cells compared to other materials ( $p<0.05$, Kruskal Wallis, Student Newman Keuls). In this period, L0.05\% no statistical difference with $\mathrm{L} 0.4 \%(p=0.90)$ was observed. However, the two membranes presented a difference in the amount of polymorphonuclear cells with LO\% at 3 and 7 days (Figure 2b).

At 7 days, the microscopic images obtained from all groups reveal a significant increase in

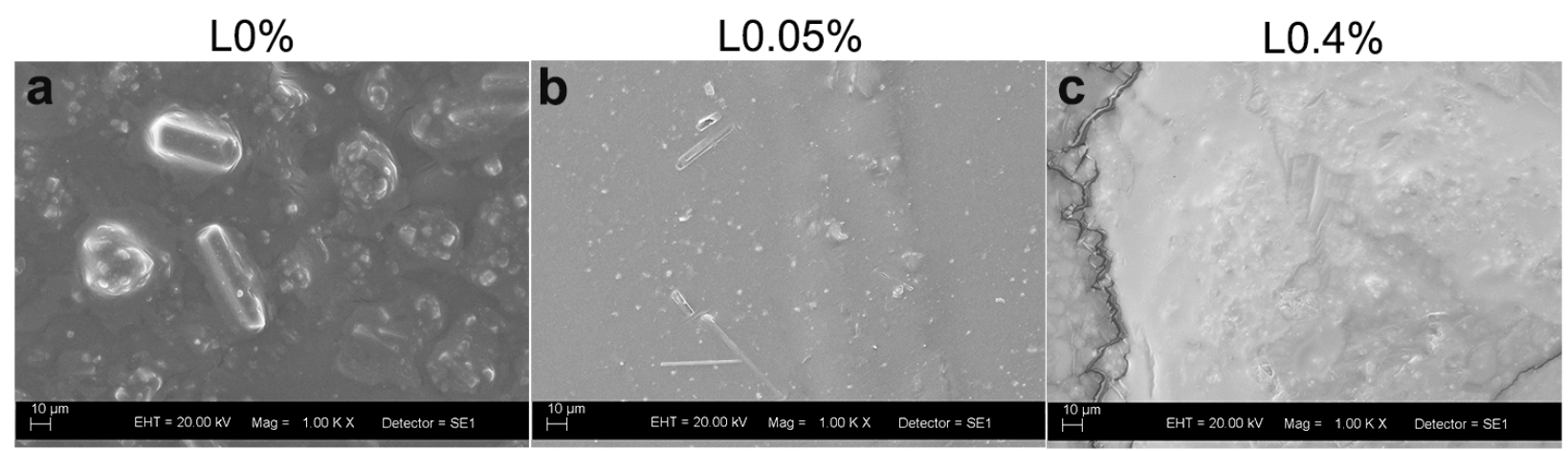

Figure 1. SEM images show the surface of the latex membranes without contamination. In (a) pure latex $0 \%$ is observed the presence of natural sugar crystals that are part of the composition of the natural latex, in (b) latex $\mathbf{0 . 0 5 \%}$ the crystals are observed in smaller size and quantity and (c) latex $0.4 \%$ of AgNP crystals are not visible, both types of membranes analyzed did not show porosity. 
the number of fibroblasts. The inflammatory infiltration was still present, but with a predominance of mononuclear cells (Figure 2a).

The number of mononuclear cells quantified for the L.0\%, L0.05\% and L0.4\% groups was similar, and did not present a statistically significant difference in any of the analyzed periods ( 3 days, $p=0.10 ; 7$ days, $p=0.99$ and 25 days, $p=0.12$; Figure $2 b$ ).

After 25 days post-surgery, there was a decrease in the number of cells of the inflammatory infiltrate (Figure 2b). The connective tissue was remodeled in the regions surrounding the biomaterials with deposition of dense collagen fibers, some giant phagocytic cells were visualized.

The angiogenic activity of latex provided intense neovascularization, as shown in Figure 3a. The neoformation of blood capillaries is similar among the groups, there is no statistical difference at 3 and 25 days ( $p=0.34$ and $p=0.21$ Kruskal Wallis), however, L0.05\% had a higher number of blood capillaries compared to LO\% and L0.4\%, ( $p<0.0001$ and $p=0.001$ Kruskal Wallis, respectively) at 7 days (Figure $3 b$ ).

Table I summarize the quantitative data on inflammatory cells and blood vessels obtained in the studied periods.

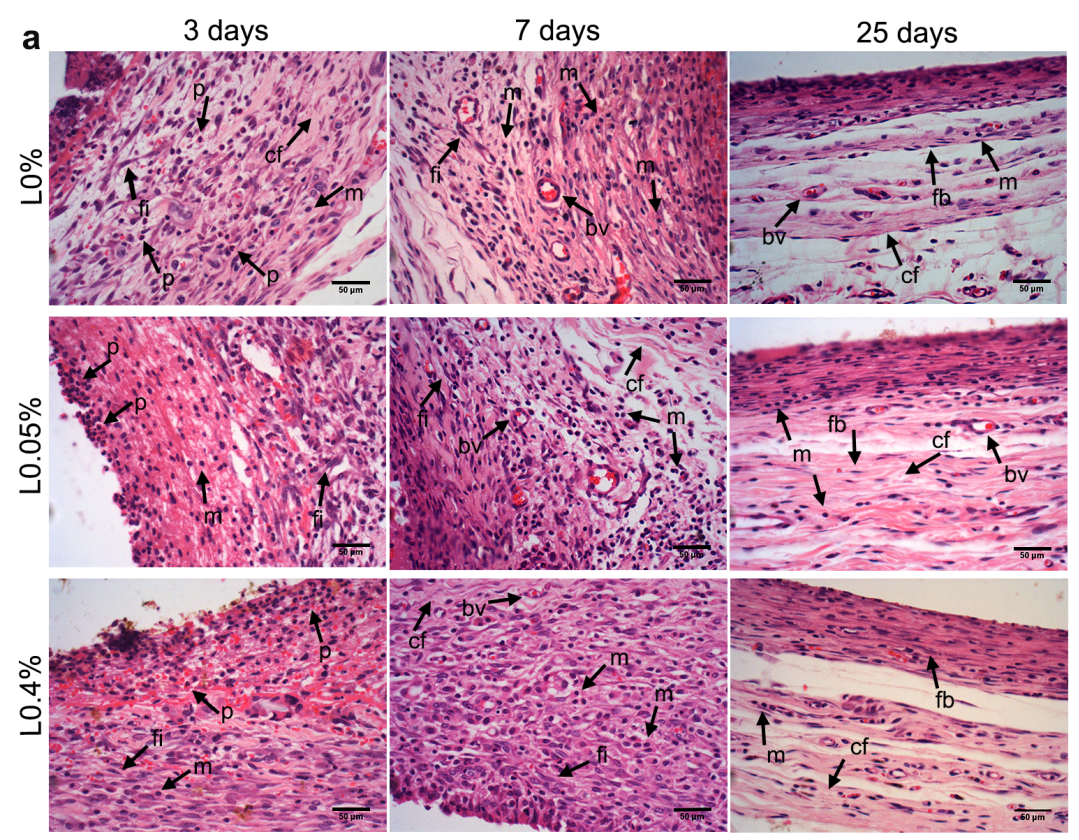

b

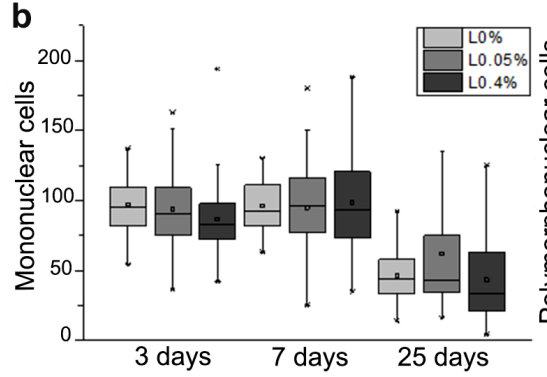

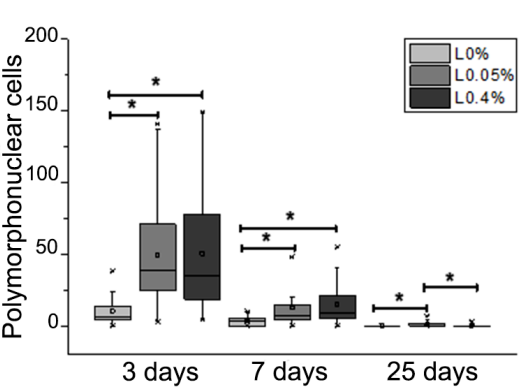

Figure 2. Photomicrographs of the subcutaneous tissue in the implantation region surrounding of the biomembranes. (a) show similar tissue response presented by groups L0\%, $\mathrm{L} 0.05 \%$, L0.4\% analyzed in periods of 3,7 and 25 days after surgery. The acute inflammatory infiltrate was present around the implanted materials in 3 days, transiting to chronic infiltration in 7 days and regression of the infiltrate and remodeling of the connective tissue in 25 days. bv=blood vessels; $m=$ mononuclear cell; $p=$ polymorphonuclear cells; $\mathrm{fi}=\mathrm{fibroblast}$; $\mathrm{fb}=$ fibrocytes; $\mathrm{cf}=$ collagen fiber. $\mathrm{H} \& \mathrm{E}$ staining, magnification 400x. (b) bloxplot graphs show the number of mononuclear and polymorphonuclear cells quantified in periods of 3,7 and 25 days, in both periods there was no statistical difference between the groups $\mathrm{L} 0 \%, \mathrm{~L} 0.05 \%, \mathrm{~L} 0.04 \%$ as $\mathrm{n}(p<0.05$, Kruskal Wallis-Student Newman Keuls), indicated by the symbol (*), showed a higher number of polymorphonuclear cells in the period of 3 and 7 days $(p<0.05)$. 

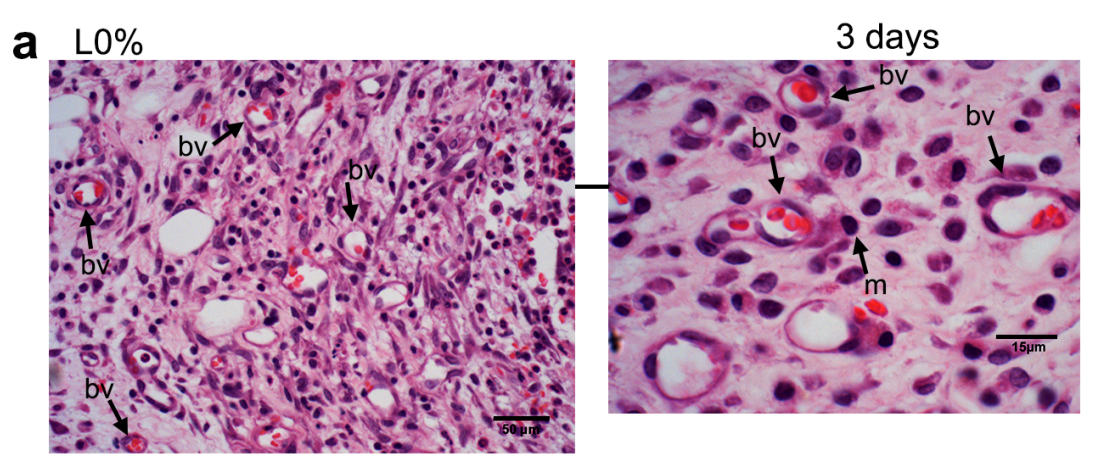

Figure 3. Photomicrographs show in (a) intense neovascularization at 3 days for both groups analyzed. $b v=$ blood vessels; $m=$ mononuclear cell. (b) bloxpot graph shows no number of blood capillaries quantified for $\mathrm{L} 0 \%, \mathrm{~L} 0.05 \%$ and L0.4\% in 3, 7, 25 days, it was observed that the angiogenic process remained constant over time. H\&E staining, magnification

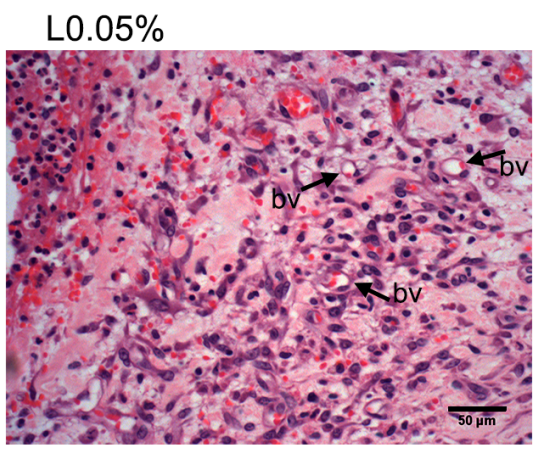
$\mathrm{L} 0.4 \%$ 400x and 1000x.

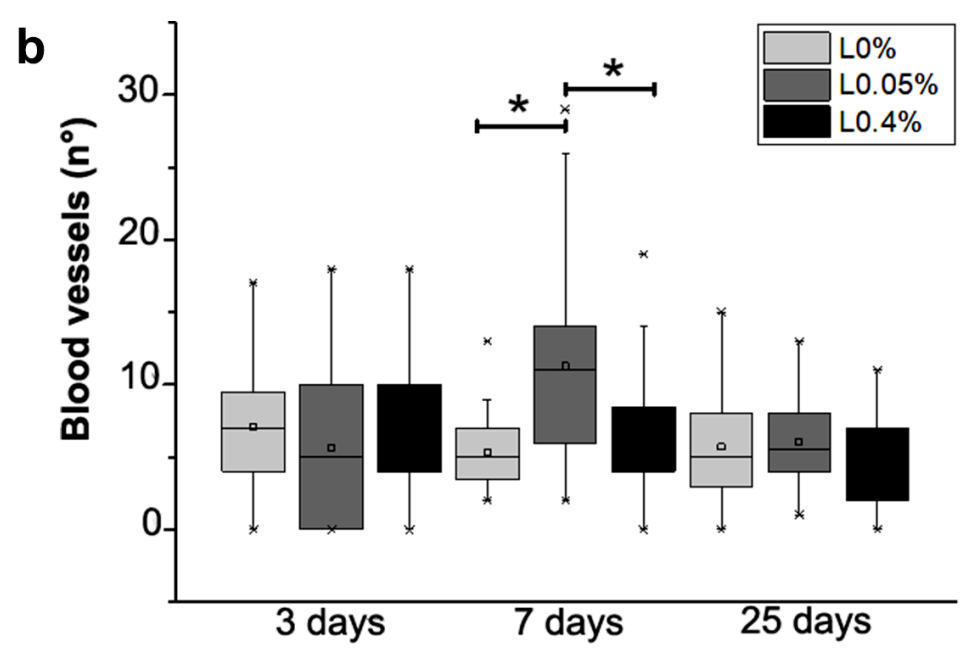

\section{Anti-biofilm tests}

The mean and standard deviation of OD for biomass determination are: $1.354 \pm 0.003$ (LO\%); $0.150 \pm 0.005$ (L0.05\%) and $0.107 \pm 0.06$ (L0.4\%). Analysis of variance (ANOVA) followed by Tukey test indicate statistical differences in the $\mathrm{L} 0.05 \%$ and $\mathrm{L} 0.4 \%$ results in comparison to L0\% $(p<0.05$, ANOVA, Tukey) demonstrating the reduction of biofilm biomass due to AgNP. L0.4\% presented a slightly sticky surface, causing handling difficulties during the test, and deformities in the membrane, thus affecting the optical density. This explains higher standard deviation and probably the absence of statistical difference with L0.05\% membrane.

SEM images were taken to analyze the viability of the bacterial biofilm formed on the surface of the incorporated biomembranes after incubation with S. aureus for $24 \mathrm{~h}$. Figure $4 a, b$ shows bacterial adhesion on the surface 
of L0\% and L0.05\%, respectively. LO\% presented bacterial biofilm on its surface, formed by large clusters of cells adhered to the surface and in between, in 3-4 cell layers, with rounded cell format. In addition, a continuous extracellular matrix can be observed, indicating bacterial multiplication (Figure 4a).

SEM images of L0.05\% revealed the presence of prominent biofilm aggregates. They consisted of living and dead cells, and it was possible to observe an increase in the surface roughness of the colonies. This cell crenation process indicates the weakening of the biofilm structure, due to AgNP activity, causing the death of bacterial cells within the biofilm. Lower bacterial amount and adhesion, irregular cell size and shape, are some of the characteristics that evidence the anti-biofilm action of AgNP against S. aureus. Small clusters with maximum of 2 layers are observed (Figure 4b). No S. aureus biofilm formation was observed on the surface of L0.4\% (Figure 4C).

\section{DISCUSSION}

The angiogenic activity and acceleration of the cicatricial process promoted by the natural latex extracted from $\mathrm{H}$. brasilienses has been the subject of several studies that allowed the development of dermatological products such as ointments based on latex, currently marketed in the pharmacological industry indicated for cicatrization (Regederm ${ }^{\circledR}$ )Pelenova Biotecnoligia SA. Latex obtained from $\mathrm{H}$. speciosa became an alternative proposal to the use of $\mathrm{H}$. brasilienses latex due to its low amount of protein and high potential for angiogenic activity (Almeida et al. 2014, Malmonge et al. 2009). In this study, we evaluated the post-implant tissue reaction of latex biomembranes L0\% (without AgNP), L0.05\%

Table I. Median (First Line), Minimum and Maximum Values (Second Line) of Mononuclear Cells (M) polyphorphonuclear (P) and Blood Vessels (BV) according to the period and the implanted material.

\begin{tabular}{|c|c|c|c|c|c|c|c|c|c|}
\hline & \multicolumn{3}{|c|}{3 Days } & \multicolumn{3}{|c|}{7 Days } & \multicolumn{3}{|c|}{25 Days } \\
\hline & $M$ & $\mathbf{P}$ & BV & $M$ & $\mathbf{P}$ & BV & $M$ & $\mathbf{P}$ & BV \\
\hline $\begin{array}{c}\mathbf{L} \mathbf{0} \% \\
\text { Median }\end{array}$ & 95 & 6.5 & 7 & 92.5 & 3 & 5 & 43.5 & 0 & 5 \\
\hline Min-Max & $54-137$ & $0-38$ & $0-17$ & $63-130$ & $0-10$ & $2-13$ & $14-92$ & $0-0$ & $0-15$ \\
\hline $\begin{array}{l}\mathbf{L} \mathbf{0 . 0 5 \%} \\
\text { Median }\end{array}$ & 90.5 & 39 & 5 & 96 & 7 & 11 & 43 & 0 & 5.5 \\
\hline Min-Max & $36-163$ & $3-141$ & $0-18$ & $25-180$ & $0-48$ & $2-29$ & $16-260$ & $0-7$ & $1-13$ \\
\hline $\begin{array}{l}\mathbf{L} \mathbf{0 . 4 \%} \\
\text { Median }\end{array}$ & 82.5 & 35 & 7 & 93 & 9 & 6 & 33.5 & 0 & 4 \\
\hline Min-Max & $42-194$ & $4-149$ & $0-18$ & $35-188$ & $0-55$ & $0-19$ & $4-125$ & $0-3$ & $0-11$ \\
\hline
\end{tabular}


and L0.4\% (with AgNP) at 3, 7 and 25 postoperative days, as well as their anti-biofilm activity against S. aureus.

\section{Histopathological analysis}

The results show foreign body reaction in the surrounding tissue for the implants of L0\%, L0.05\% and L0.4\%, characterized by the presence of inflammatory infiltrate and phagocytic cells. However, no intense reaction was identified. Inflammatory reaction followed by cell proliferation, extracellular matrix deposition and tissue remodeling are part of the healing process (Eming et al. 2014). In 3 days, the tissue reaction to the biomembrane implant showed acute infiltration. Infiltration of polymorphonuclear cells around $\mathrm{L} 0.05 \%$ and L0.4\% implants were more intense, compared to L0\%. Polymorphonuclear leukocytes, specifically segmented neutrophils, arise immediately after an injury, these leave the blood vessels through the endothelial wall, migrating to the affected site (Eming et al. 2007). Fibroblasts are stimulated to proliferate in the first days after injury, migration is brought through factors such as TGF- $\beta$ and PDGF released by inflammatory cells and platelets (Velnar et al. 2009). In fact, the inflammatory process is necessary for the initiation of tissue remodeling after injury. a

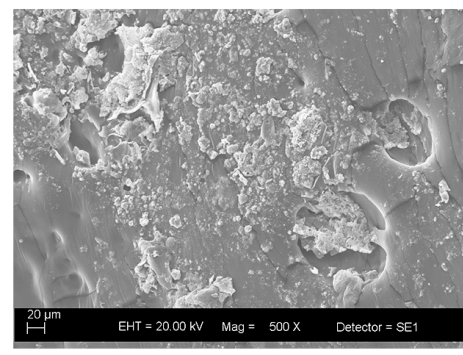

b

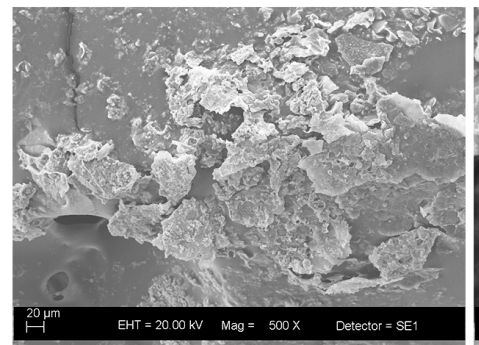

C

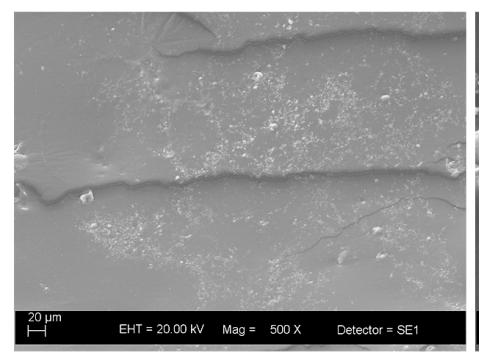

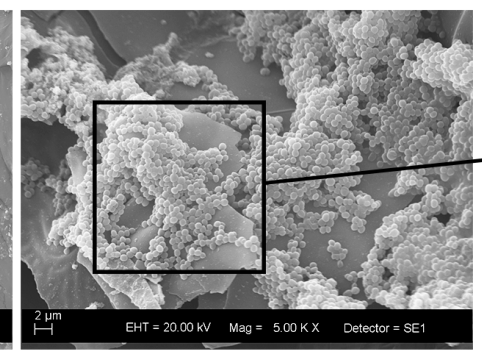
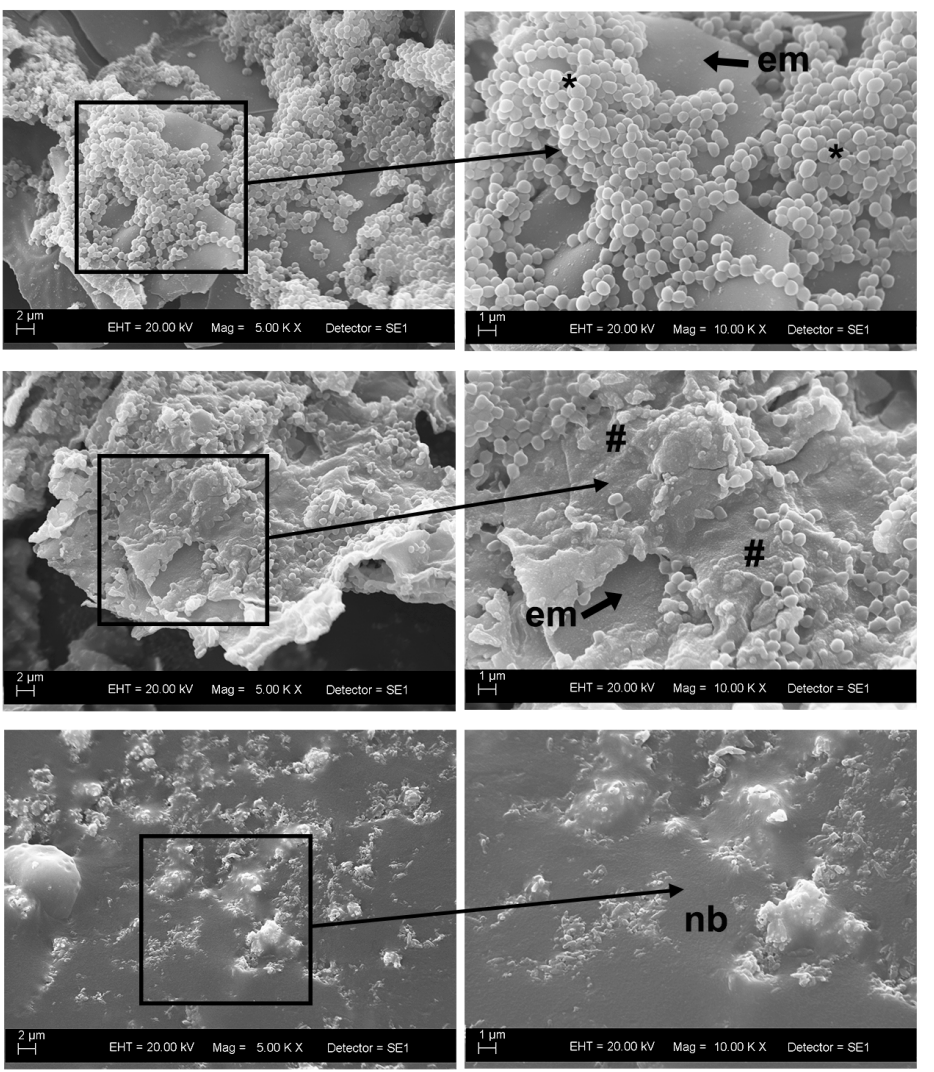

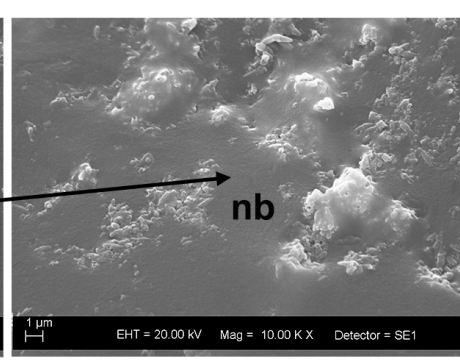

Figure 4. SEM images shows the surface of latex membranes LO\%, L0.05\% and L0.4\% after contamination and incubation with S. aureus for a period of $24 \mathrm{~h}$. (a) shows the surface of $\mathrm{L} 0 \%$, showing the formation of bacterial biofilm, represented by *. (b) shows the surface of $\mathbf{L} 0.05 \%$, the biofilm formed in this group presented structural damage caused by AgNPs, the presence of crenate cells with irregular shape (\#), and lower biological load comparing to $\mathrm{L} 0 \%$. (c) shows the surface of $0.4 \%$, there was no formation of bacterial biofilm. $\mathrm{nb}=$ no biofilm formation, em = extracellular matrix. 
At 7 days, the presence of chronic inflammatory infiltrate, mononuclear cell predominance, fibroblast proliferation and collagen fiber deposition were observed. cytokines released by inflammatory cells assist in recruitment of defense cells, growth factors stimulate proliferation of fibroblasts and induce neovascularization (Banda et al. 1982), important events for the repair process. At 25 days, a slight infiltration of mononuclear cells and giant phagocytic cells was visible in the tissue surrounding the L0\%, L0.05\% and L0.4\% implant. In addition, the decrease in the number of inflammatory cells and increase in the number of fibroblasts, dense deposition of collagen fibers in the extracellular matrix and the presence of fibrocytes (Figure 2a, 25 days) indicate regression of the inflammatory phase and progression of the tissue remodeling phase. Mononuclear lymphocytes participate in the chronic phase of inflammation, their main function is to exert chemotaxis with resident and circulating cells (Eming et al. 2009). The deposition of collagen fibers in the extracellular matrix by fibroblasts and their differentiation in myofibroblasts are important for wound contraction (Dinda et al. 2015).

In this study, the tissue reaction against the implantation of $H$. speciosa latex biomembranes incorporated by AgNP followed the chronology of the tissue repair process initiated by an inflammation phase, followed by remodeling of the subcutaneous tissue. Angiogenic activity was assessed by quantitative analysis of the photomicrographs, observing and counting the new blood capillaries. The observed neovascularization remained constant throughout the periods for both L0\%, L0.05\% and L0.4\% groups. Almeida et al. 2014 showed that latex obtained from $\mathrm{H}$. speciosa and diluted in water has significant angiogenic activity and does not present cytotoxic or genotoxic effects.
Thus, we conclude that angiogenic activity must be associated with latex $H$. speciosa and AgNPs does not interfere in this process. In the 7-day period the blood capillaries quantified for the $\mathrm{L} 0.05 \%$ and $\mathrm{L} 0.4 \%$ membranes were larger compared to LO\% (Figure 3b).

\section{Effect of AgNP against biofilm}

Anti-biofilm activity of AgNP was analyzed against S. aureus. Our results show that, on the surface of the L0\% (latex without AgNP) group, the S. aureus biofilm formed after $24 \mathrm{~h}$ of incubation, however biomembranes impregnated with AgNP prevented and damaged the biofilm structure according to the concentration (Figure 4b, c). Experiments carried out to analyze the antimicrobial efficacy of dressings with silver already commercialized show that dressings based on hydrophobic material incorporated with silver nanocrystalline (Acticoat ${ }^{\circledR}$ ) showed a greater anti-biofilm efficacy for a prolonged time, verifying that after interaction with the silver released by the curative, bacteria became more susceptible to the effects of antibiotics (Kostenko et al. 2010). A nanocrystalline silver curative dressing (Acticoat ${ }^{\circledR}$ ) has demonstrated greater efficiency against Methicillin-resistant $S$. aureus (MRSA) compared to other silver dressing formulations and is promising in the treatment of wounds infected by this bacterium (Lee et al. 2010).

There was no formation of bacterial biofilm on the surface of the higher silver nanoparticles concentration (L0.4\%). However, at the lower concentration (L.0.05\%) there were cellular and structural damage on the biofilm formation. Crenate bacteria (irregular shape, indication of cell death) were observed and also and reduction of biofilm biomass (OD 1.356 from LO\% to OD 0.150 from L0.05\%). The efficacy of the AgNP solution as an anti-biofilm agent was demonstrated against $S$. aureus and $P$. 
aeruginosa at concentrations of $0.7 \mu \mathrm{g} / \mathrm{mL}$ and $0.5 \mu \mathrm{g} / \mathrm{mL}$ (Gurunathan et al. 2014). As already mentioned, biofilm formed on the surface of $0.05 \%$ presented cellular and structural damage, this efficiency is related to the high fixation and penetration capacity of AgNP through the cell membrane and its accumulation inside the cell (Rai et al. 2009). A previous study reports that AgNP prevented the formation of S. aureus biofilm by means of a supposed neutralizing effect of adhesive substances (Chaudhari et al. 2012). Olson et al. 2002 have shown that S. aureus biofilm has high resistance to antibiotics, causing infections in chronic wounds that lead to severe inflammatory responses and consequently delayed healing process (Zhao et al. 2013).

\section{CONCLUSION}

Our in vivo tests results showed that the incorporation of silver nanoparticles into the latex did not interfere in the natural process of inflammation and restoration of the subcutaneous tissue after the implants of the materials tested. Also, it did not interfere with the angiogenic activity of $H$. speciosa latex. The in vitro test for analysis of AgNP anti-biofilm activity showed that $0.4 \%$ of AgNP incorporated into the latex of $H$. speciosa completely inhibited the formation of $S$. aureus biofilm, whereas $0.05 \%$ AgNP caused severe damage to the structure of the biofilm. Latex alone did not present anti-biofilm activity. Therefore, membranes composed of $H$. speciosa latex incorporated with $0.4 \%$ AgNPs showed high efficiency in the anti-biofilm activity, without damaging the subcutaneous tissue after the implants, suggesting being a promising material for future applications in the regeneration area of cutaneous wounds.

\section{Acknowledgments}

The authors would like to thank the Fundação de Amparo à Pesquisa do Estado de São Paulo (FAPESP 2016/063990 and Neuromat 13/07699-0), to Instituto de Pesquisas Energéticas e Nucleares (IPEN) for the irradiation of the materials, to Coordenação de Aperfeiçoamento de Pessoal de Nivel Superior, [CAPES, Finance Code 001], Conselho Nacional de Desenvolvimento Científico e Tecnológico, grant number [CNPq code 304107/20190] to technicians Wilson Orcini, Maira Couto from the Universidade do Sagrado Coração, and to Rodrigo Silva, from Universidade de São Paulo.

\section{REFERENCES}

AHAMED M, ALSALHI MS \& SIDDIQUI MKJ. 2010. Silver nanoparticle applications and human health. Clin Chim Acta 411: 1841-1848.

ALMEIDA LM ET AL. 2014. Hancornia speciosa latex for biomedical applications: Physical and chemical properties, biocompatibility assessment and angiogenic activity. J Mater Sci: Mater Med 25: 2153-2162.

ALMEIDA LM, MAGNO LN, PEREIR AC, GUIDELLI EJ, BAFFA, KINOSHITA A \& GONÇALVES PJ. 2019. Toxicity of silver nanoparticles released by hancornia speciosa (mangabeira) biomembrane. Spectrochim Acta A Mol Biomol Spectrosc 210: 329-334.

BANDA MJ, KINIGHTON DR, HUNT TK \& WERB Z. 1982. Isolation of a nonmitogenic angiogenesis factor from wound fluid. Proc Natl Acad Sci USA 79: 7773-7777.

BERTHELOT K, LECOMTE S, ESTEVEZ Y, COULARY-SALIN B, BENTALEB A, CULLIN C, DEFFIEUX A \& PERUCH F. 2012. Rubber Elongation Factor (REF), a Major Allergen Component in Hevea brasiliensis Latex Has Amyloid Properties. PLoS ONE 7: 1-12.

BORSARI FN, LEAL LM, FREITAS HMG, SASAHARA THC \& MACHADO MRF. 2014. Application of natural latex membrane and extract of frog skin (Lithobates catesbiana) in cutaneous surgical wounds of Wistar rats. R Bras Ci Vet 21: 150-155.

CARTER MJ, TINGLEY-KELLEY K \& WARRINER RA. 2010. Silver treatments and silver-impregnated dressings for the healing of leg wounds and ulcers: A systematic review and meta-analysis. J Am Acad Dermatol 63: 668-679.

CHALOUPKA K, MALAM Y \& SEIFALIAN AM. 2010. Nanosilver as a new generation of nanoproduct in biomedical applications. Trends Biotechnol 28: 580-588. 
CHAMBERS H, DUMVILLE JC \& CULLUM N. 2007. Silver treatments for leg ulcers: a systematic review. Wound Rep Reg 15: 165-173.

CHAUDHARI PR, MASURKAR SA, SHIDORE VB \& KAMBLE SP. 2012. Effect of Biosynthesized Silver Nanoparticles on Staphylococcus aureus Biofilm Quenching and Prevention of Biofilm Formation. Nano-Micro Lett 4: 34-39.

CHRISTENSEN GD, SIMPSON WA, YOUNGER JJ, BADDOUR LM, BARRETT FF, MELTON DM \& BEACHEY EH. 1985. Adherence of coagulase-negative staphylococci to plastic tissue culture plates: A quantitative model for the adherence of staphylococci to medical devices. J Clin Microbiol 22: 996-1006.

DINDA M, DASGUPTA U, SINGH N, BHATTACHARYYA D \& KARMAKAR P. 2015. PI3K-Mediated proliferation of fibroblasts by calendula officinalis tincture: Implication in wound healing. Phytother Res 29: 607-616.

DOS SANTOS NEVES J, FRANCHIN M, ROSALEN PL, OMAR NF, SANTOS MA, PASCHOAL JAR \& NOVAES PD. 2016. Evaluation of the osteogenic potential of Hancornia speciosa latex in rat calvaria and its phytochemical profile. J Ethnopharmacol 183: 151-158.

EBO DG \& STEVENS WJ. 2002. IGE-mediated natural rubber latex allergy: an update. Acta Clin Belg 57: 58-70.

EMING SA, HAMMERSCHMIDT M, KRIEG T \& ROERS A. 2009. Interrelation of immunity and tissue repair or regeneration. Semin Cell DevBiol 20: 517-527.

EMING SA, KRIEG T \& DAVIDSON JM. 2007. Inflammation in wound repair: Molecular and cellular mechanisms. J Invest Dermatol 127: 514-525.

EMING SA, MARTIN P \& TOMIC-CANIC M. 2014. Wound repair and regeneration: Mechanisms, signaling, and translation. Sci Transl Med 6: 1-16.

ERENO C, GUIMARÃES SAC, PASETTO S, HERCULANO RD, SILVA CP, GRAEFF CFO, TAVANO O, BAFFA O \& KINOSHITA A. 2010. Latex use as an occlusive membrane for guided bone regeneration. J Biomed Mater Res A 95: 932-939.

FLORIANO JF ET AL. Comparative study of Bone tissue accelerated regeneration by latex membranes from Hevea brasiliensis and Hancornia speciosa. Biomed Phys Eng Express 2: 1-15.

FRADE MAC, VALVERDE RV, ASSIS RVC, COUTINHO-NETTO J \& FOSS NT. 2001. Chronic phlebopathic cutaneous ulcer:a therapeutic proposal. Int J Dermatol 40: 237-240.

GELLER FC, TEIXEIRA MR, PEREIRA ABD, DOURADO LPA, SOUZA DG, BRAGA FC \& SIMÕES CMO. 2015. Evaluation of the Wound
Healing Properties of Hancornia speciosa Leaves. Phytother Res 29: 1887-1893.

GUIDELLI EJ, KINOSHITA A, RAMOS AP \& BAFFA O. 2013. Silver nanoparticles delivery system based on natural rubber latex membranes. J Nanopart Res 15: 1-9.

GURUNATHAN S, HAN JW, KWON DN \& KIM JH. 2014. Enhanced antibacterial and anti-biofilm activities of silver nanoparticles against Gram-negative and Gram-positive bacteria. Nanoscale Res Lett 9: 1-17.

HEBEISH A, EL-RAFIE MH, EL-SHEIKH MA, SELEEM AA \& ELNAGGAR ME. 2014. Antimicrobial wound dressing and antiinflammatory efficacy of silver nanoparticles. Int J Biol Macromol 65: 509-515.

INTERNATIONAL CONSENSUS. 2012. Appropriate use of silver dressings in wounds. An expert working group consensus. London: Wounds International.

JUNIOR JFS, MOTA DM, SCHMITZ H \& RODRIGUES RFA. 2017. Mangabeira: uma espécie historicamente pernambucana. Arrudea 3: 2-22.

KALISHWARALAL K, KANTH SBM, PADIAN SRK, DEEPAK $V$ \& GURUNATHAN S. 2010. Silver nanoparticles impede the biofilm formation by Pseudomonas aeruginosa and Staphylococcus epidermidis. Colloids Surf B Biointerfaces 79: 340-344.

KIM JS ET AL. 2007. Antimicrobial effects of silver nanoparticles. Nanomed Nanotechnol Biol Med 3: 95-101.

KOSTENKO V, LYCZAK J, TURNER K \& MARTINUZZI RJ. 2010. Impact of Silver-Containing Wound Dressings on Bacterial Biofilm Viability and Susceptibility to Antibiotics during Prolonged Treatment. Antimicrob Agents Chemother 54: 5120-5131.

LEE JH, CHAE JD, KIM DG, HONG SH, LEE WM \& KI M. 2010. Comparison of the efficacies of silver-containing dressing materials for treating a full-thickness rodent wound infected by methicillin-resistant Staphylococcus aureus. Korean J Lab Med 30: 20-27.

MALMONGE JA, CAMILLO EC, MORENO, MATTOSO LHC \& MCMAHAN CM. 2009. Comparative Study on the Technological Properties of Latex and Natural Rubber from Hancornia speciosa Gomes and Hevea brasiliensis. J Appl Polym Sci 111: 2986-2991.

MARINHO DG, ALVIANO DS, MATHEUS ME, ALVIANO CS \& FERNANDES PD. 2011. The latex obtained from Hancornia speciosa Gomes possesses anti-inflammatory activity. J Ethnopharmacol 135: 530-537.

MARQUES L ET AL. 2013. Subcutaneous tissue reaction and cytotoxicity of polyvinylidene fluoride and 
polyvinylidene fluoride-trifluoroethylene blends associated with natural polymers. J Biomed Mater Res Part B 101: 1284-1293.

MEDEIROS ES, GALIANI PD, MORENO RMB, MATTOSO LHC \& MALMONGE JA. 2010. A comparative study of the non-isothermal degradation of natural rubber from Mangabeira (Hancornia speciosa Gomes) and Seringueira (Hevea brasiliensis). J Therm Anal Calorim 100: 1045-1050.

MOURA JML, FERREIRA JF, MARQUES L, HOLGADO L, GRAEFF CFO \& KINOSHITA A. 2014. Comparison of the performance of natural latex membranes prepared with different procedures and PTFE membrane in guided bone regeneration (GBR) in rabbits. J Mater Sci Mater Med 50: 2111-2120.

OLSON ME, CERI H, MORCK DW, BURET AG \& READ RR. 2002. Biofilm bacteria: Formation and comparative susceptibility to antibiotics. Can J Vet Res 66: 86-92.

RADZIG MA, NADTOCHENKO VA, KOKSHAROVA OA, KIWI J, LIPASOVA VA \& KHMEL IA. 2013. Antibacterial effects of silver nanoparticles on gram-negative bacteria: Influence on the growth and biofilms formation, mechanisms of action. Colloid Surfaces B 102: 300-306.

RAI M, YADAV A \& GADE A. 2009. Silver nanoparticles as a new generation of antimicrobials. Biotechnol Adv 27: 76-83.

RIBEIRO TP, SOUSA TR, ARRUDA AS, PEIXOTO N, GONÇALVES PJ \& ALMEIDA LM. 2016. Evaluation of cytotoxicity and genotoxicity of Hancornia speciosa latex in Allium cepa root model. Braz J Biol 76: 245-249.

SCHNEIDER CA, RASBAND WS \& ELICEIRI KW. 2012. "NIH Image to Image): 25 years of image analysis". Nat Methods 9: 671-675.

SOARES FP, PAIVA R, NOGUEIRA RC, OLIVEIRA LM, SILVA DRG \& PAIVA PDO. 2004. Cultura da Mangabeira (Hancornia speciosa Gomes), p. 1-12.

TORRES-RÊGO M ET AL. 2016. Anti-inflammatory activity of aqueous extract and bioactive compounds identified from the fruits of Hancornia speciosa Gomes (Apocynaceae). BMC Compl Alternative Med 16: 1-10.

VAN MINNEN B, VAN LEEUWEN MBM, STEGENGA B, ZUIDEMA J, HISSINK CE, VAN KOOTEN TG \& BOS RRM. 2005. Short-term in vitro and in vivo biocompatibility of a biodegradable polyurethane foam based on 1,4-butanediisocyanate. J Mater Sci Mater Med 16: 221-227.

VELNAR T, BAILEY T \& SMRKOLJ V. 2009. The Wound Healing Process: An Overview of the Cellular and Molecular Mechanisms. J Int Med Res 37: 1528-1542.
WILKINSON LJ, WHITE RJ \& CHIPMAN JK. 2011. Silver and nanoparticles of silver in wound dressings: a review of efficacy and safety. J Wound Care 20: 543-549.

ZHANG L, GU FX, CHAN JM, WANG AZ, LANGER RS \& FAROKHZAD OC. 2008. Nanoparticles in medicine: Therapeutic applications and developments. Clin Pharmacol Ther 83: 761-769.

ZHAO G, USUI ML, LIPPMAN SI, JAMES GA, STEWAART PS, FLECKMAN P \& OLERUD JE. 2013. Biofilms and Inflammation in Chronic Wounds. Adv Wound Care 2: 389-399.

\section{How to cite}

BONETE JM, SILVA GD, GUIDELLI EJ, GONÇALVES PJ, ALMEIDA LM, BAFFA O \& KINOSHITA A. 2020. Tissue reaction and anti-biofilm action of new biomaterial composed of latex from Hancornia speciosa Gomes and silver nanoparticles. An Acad Bras Cienc 92: e20191584. DOI 10.1590/00013765202020191584.

Manuscript received on December 19, 2019;

accepted for publication on March 6, 2020

\section{JÉSSICA M. BONETE ${ }^{1}$}

https://orcid.org/0000-0001-9914-4247

GUILHERME D. SILVA ${ }^{1}$

https://orcid.org/0000-0002-5427-1231

\section{ÉDER J. GUIDELLI ${ }^{2}$}

https://orcid.org/0000-0002-4657-5112

\section{PABLO J. GONÇALVES 3}

https://orcid.org/0000-0003-0246-1073

LUCIANE M. ALMEIDA ${ }^{4}$

https://orcid.org/0000-0003-1764-1480

\section{OSWALDO BAFFA ${ }^{2}$}

https://orcid.org/0000-0002-0622-2814

\section{ANGELA KINOSHITA ${ }^{5,6}$}

https://orcid.org/0000-0002-5057-1667 
${ }^{1}$ PRPPG, Universidade do Sagrado Coração/USC, Rua Irmã Arminda, 10-50, Bauru, 17011-160 SP, Brazil

${ }^{2}$ Universidade de São Paulo/FFCLRP, Departamento de Física, Av. Bandeirantes, 3900, 14049-900 Ribeirão Preto, SP, Brazil

${ }^{3}$ Universidade Federal de Goiás/UFG, Instituto

Física, Av. Esperança, s/n, Campus Samambaia, 14049-900 Goiânia, GO, Brazil

${ }^{4}$ Universidade Estadual de Goiás/UEG, BR-153 3105, Fazenda Barreiro do Meio, Campus Anápolis de Ciências Exatas e Tecnológicas, 75132-400 Anápolis, GO, Brazil ${ }^{5}$ PPGMADRE, Universidade do Oeste Paulista/UNOESTE, SP-270, Km 572, 19067-175 Presidente Prudente, SP, Brazil ${ }^{6}$ Curso de Odontologia, Faculdade do Centro Oeste Paulista/FACOP, Rua Luiz Gimenez Mocegose, 72,

Distrito Industrial, 17490-000 Piratininga, SP, Brazil

Correspondence to: Angela Kinoshita

E-mail:angelamitie@gmail.com

\section{Author contributions}

Conceptualization: PG, LA, AK; Methodology: JB, GD, ED, PG, LA, $O B, A K$; Formal analysis: JB, ED, PG, LA, OB, AK; Investigation: JB, $G D, E D, P G, L A$; Resources: $O B, A K$; Writing Original Draft: JB, ED, $P G, A K$; Writing Review \& Editing: JB, ED, PG, LA, OB, AK.

\section{(cc) BY}

